\title{
Targeted disruption of the glucocorticoid receptor gene blocks adrenergic chromaffin cell development and severely retards lung maturation
}

\author{
Timothy J. Cole, Julie A. Blendy, A. Paula Monaghan, Kerstin Krieglstein, ${ }^{1}$ Wolfgang Schmid, \\ Adriano Aguzzi, ${ }^{2}$ Giamila Fantuzzi, ${ }^{3}$ Edith Hummler, ${ }^{4}$ Klaus Unsicker, ${ }^{1}$ and Günther Schütz ${ }^{5}$ \\ Division of Molecular Biology of the Cell I, German Cancer Research Center, 69120 Heidelberg, Germany; ${ }^{1}$ Department \\ of Anatomy and Cell Biology, University of Heidelberg, 69120 Heidelberg, Germany; ${ }^{2}$ Institute of Neuropathology, \\ University of Zürich, 8091 Zürich, Switzerland; ${ }^{3}$ Mario Negri Institute for Pharmacology, Milano 20157, Italy
}

The role of the glucocorticoid receptor (GR) in glucocorticoid physiology and during development was investigated by generation of GR-deficient mice by gene targeting. GR $-/-$ mice die within a few hours after birth because of respiratory failure. The lungs at birth are severely atelectatic, and development is impaired from day 15.5 p.c. Newborn livers have a reduced capacity to activate genes for key gluconeogenic enzymes. Feedback regulation via the hypothalamic-pituitary-adrenal axis is severely impaired resulting in elevated levels of plasma adrenocorticotrophic hormone (15-fold) and plasma corticosterone (2.5-fold). Accordingly, adrenal glands are enlarged because of hypertrophy of the cortex, resulting in increased expression of key cortical steroid biosynthetic enzymes, such as side-chain cleavage enzyme, steroid 11ß-hydroxylase, and aldosterone synthase. Adrenal glands lack a central medulla and synthesize no adrenaline. They contain no adrenergic chromaffin cells and only scattered noradrenergic chromaffin cells even when analyzed from the earliest stages of medulla development. These results suggest that the adrenal medulla may be formed from two different cell populations: adrenergic-specific cells that require glucocorticoids for proliferation and/or survival, and a smaller noradrenergic population that differentiates normally in the absence of glucocorticoid signaling.

[Key Words: Glucocorticoids; steroid hormone receptor; lung development; chromaffin cells; gene targeting]

Received April 7, 1995; revised version accepted May 30, 1995.

The physiological effects of glucocorticoids are mediated by intracellular glucocorticoid receptors (GRs) that function as ligand-dependent transcription factors (Beato 1989|. Two highly homologous receptors able to bind glucocorticoids have been characterized and are designated the GR (type II GR), and the mineralocorticoid receptor (MR; type I GR). Upon hormonal activation the receptor translocates to the nucleus where it binds to palindromic hormone response elements situated in regulatory regions and thereby alters expression of target genes (Yamamoto 1985; Beato 1989; Evans and Arizza 1989; Clark et al. 1992). Even though MR has a higher affinity for glucocorticoids than GR, the majority of the physiological effects of glucocorticoids are thought to be mediated via the GR, which is expressed more ubiquitously and is a stronger transcriptional activator (Orth et al. 1992; Rupprecht et al. 1993). Physiologically, MR is thought to act primarily as a high affinity receptor for

${ }^{5}$ Corresponding author. mineralocorticoids to control sodium/potassium balance in the kidney and large intestine. MR also has a more restricted tissue expression pattern, being predominantly expressed in the kidney, large intestine, and brain (Arriza et al. 1987). The specificity of mineralocorticoids for MR in the kidney and large intestine is provided by the activity of the enzyme $11 \beta$-hydroxysteroid dehydrogenase, which inactivates glucocorticoids (Funder et al. 1988).

Glucocorticoid hormones synthesized in and secreted from the adrenal cortex are involved in the regulation of many physiological processes. These include control of carbohydrate and lipid metabolism, modulation of immune responses, and various physiological responses in the brain, including stress responses and behavior (Munck and Guyre 1991; Orth et al. 1992; deKloet et al. 1993). The level of glucocorticoids is tightly controlled by feedback regulation of glucocorticoid synthesis via the hypothalamic-pituitary-adrenal (HPA) axis (Chrousos 1992). At birth, glucocorticoids, in combination with other hormones, especially glucagon, activate key he- 
patic gluconeogenic enzymes such as glucose-6-phosphatase (G6Pase) and phosphoenolpyruvate carboxykinase (PEPCK) (Pilkis and Granner 1992). Glucocorticoids are important during embryonic lung development and may be involved in epithelial cell functions (Brody and Williams 1992). In the perinatal period glucocorticoids help promote surfactant synthesis in alveolar epithelial cells of the developing lung (Mendelson and Boggaram 1991) and are used effectively in the treatment of the respiratory distress syndrome of prematurely born children. Glucocorticoids are also implicated in the development of adrenal chromaffin cells (Anderson 1993a).

The embryonic adrenal begins to synthesize glucocorticoids early in its development with circulating levels of glucocorticoids rising steadily and peaking at birth (Orth et al. 1992). Not much is known about the specific role of GR and MR during embryonic development. To investigate the role of the GR during development and in various physiological processes we have produced a null mutation of the mouse GR gene by gene targeting in embryonic stem (ES) cells. The resulting GR-deficient mice develop to term, but most die shortly after birth. This paper describes the prominent developmental and biochemical defects of GR-deficient mice.

\section{Results \\ Disruption of the GR gene by homologous recombination}

The mouse GR gene was disrupted in ES cells using a replacement vector strategy, outlined in Figure 1A. A selectable marker, the neomycin phosphotransferase gene cassette (PGKNEO), was inserted into exon 2 of the mouse GR gene. The targeting vector contained $5.5 \mathrm{~kb}$ of homology and was isolated from an isogenic mouse $129 /$ J strain genomic library, as the use of isogenic DNA is known to improve the efficiency of homologous recombination (te Riele et al. 1992). To identify correctly targeted clones, 256 of $\sim 2000$ G418-resistant clones were screened by Southern blot analysis using an external $3^{\prime}$ probe (see Fig. 1A). This probe hybridizes to an 8.0-kb BgIII fragment in wild-type GR alleles but to a 5.0$\mathrm{kb}$ fragment in correctly targeted clones. Of the 256

A
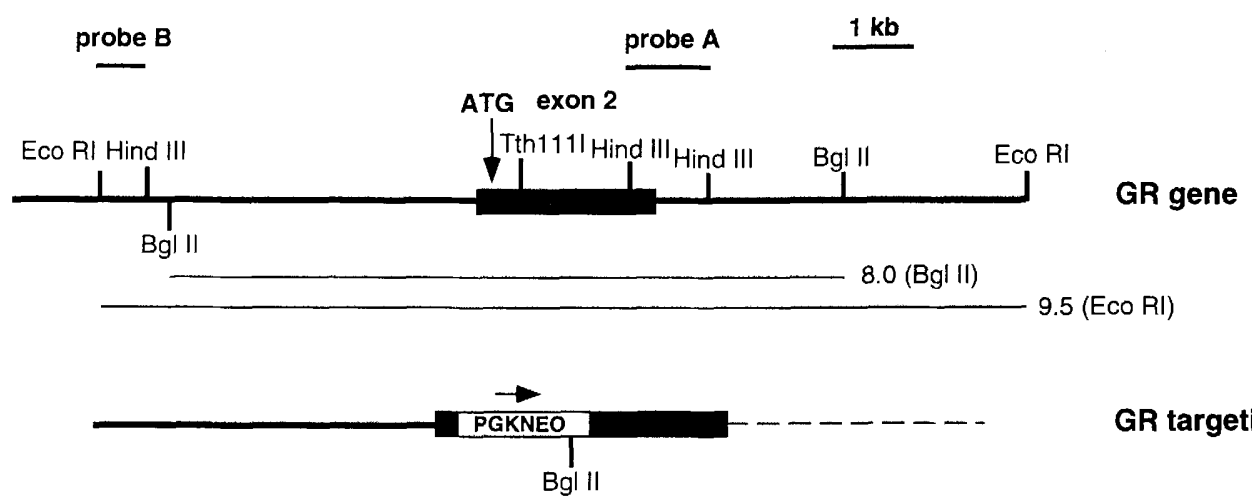

\section{GR targeting vector}

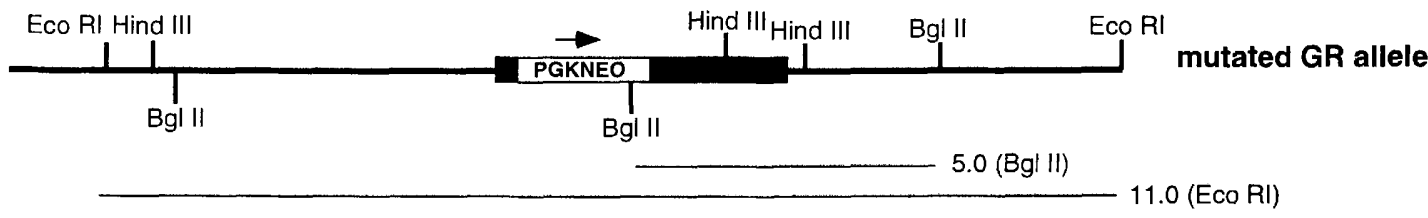

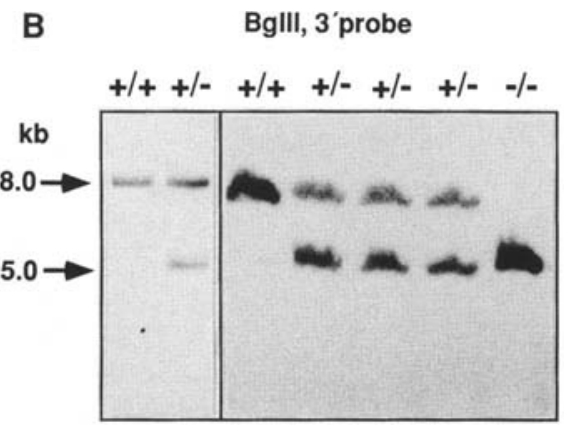

BgIII, 3 'probe

EcoRI, 5 'probe

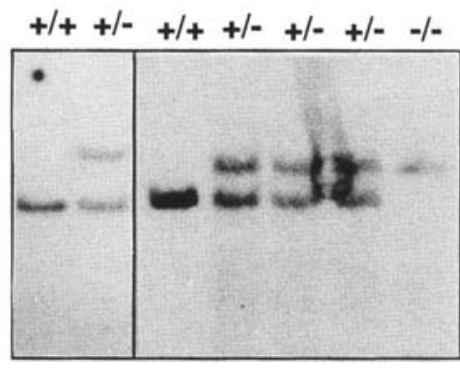

Figure 1. Inactivation of the GR gene in mouse ES cells. $(A)$ Targeting strategy. The PGK promoter-controlled neomycin-resistance gene cassette was inserted into the Tth 111 I site in exon 2 of the mouse GR gene. $(B)$ Southern blot analysis of DNA of neomycin resistant ES cell clones (left) and

kb of tail DNAs of progeny (right) from heterozygote intercrosses. DNAs were digested with either BgIII for probing from 9.5 the 3' side or with EcoRI for probing from the $5^{\prime}$ side of the disrupted GR allele. Filters were exposed for between 1 and 3 days. $1+1+1$ Wild-type; $(+1-1$ heterozygous; $(-1-)$ homozygous mutant. 
clones analyzed, $6(2 \%)$ had undergone homologous recombination to give the expected bands of 8.0 and $5.0 \mathrm{~kb}$ in an $\sim 1: 1$ stoichiometry. An example of the analysis is shown in Figure 1B (BglII, left). Correctly targeted clones were confirmed by using a second probe (probe B, Fig. 1A) situated on the $5^{\prime}$ side of the targeting vector (Fig. 1B, EcoRI left).

\section{The generation of mice homozygous for the targeted GR allele}

Three independent ES cell clones were used for injection into C57BL/ 6 blastocysts to generate chimeric mice. Chimeric mice from two clones (10 and 76) transmitted the 129/J agouti coat color to their offspring, indicating germ-line transmission. Chimeras from ES cell clone 10 were mated with both C57BL/6 and 129/J animals to generate an outbred and isogenic colony. Fifty percent of agouti offspring from chimeras were heterozygous for the GR mutated allele as determined by Southern blotting of tail DNAs. Mice homozygous for the GR mutation were generated by the intercrossing of heterozygous animals and offspring genotypes determined by Southern blotting of tail DNAs (Fig. 1B, right). Analysis of progeny genotypes (shown in Table 1) at 4 weeks showed a much reduced number of GR -1 - mutant offspring $(4.5 \%)$ indicating that most homozygous mutant animals were dying either prenatally or perinatally. To investigate the perinatal survival of GR - / - mutants 14 litters from heterozygous intercrosses were examined at birth. A high number of offspring were observed either delivered dead or dying within the first $1-2 \mathrm{hr}$. At birth $\sim 25 \%$ of offspring were genotyped as GR $-/-$, but the majority of these GR $-/$ - mutants died in the first few hours after birth, indicating that mutation of the GR leads to perinatal lethality (Table 1). So far, no surviving GR - / - animals have been obtained when this mutation has been placed into the $129 / \mathrm{J}$ isogenic mouse background (Table 1).

\section{Analysis of GR RNA and protein in $G R-/$ - mice}

Expression of the GR gene was analyzed by Northern blot analysis using a specific 520-nucleotide antisense RNA probe derived from exon 2 of the mouse GR gene (Strähle et al. 1992). Figure 2A shows a Northern blot analysis of lung RNA from newborn mice of all three genotypes. No full-length GR transcripts could be de-

Table 1. Genotypes of progeny of heterozygote intercrosses

\begin{tabular}{llrrl}
\hline Progeny & Genotypes & \multicolumn{1}{l}{$l+$} & \multicolumn{1}{l}{$+1-$} & \multicolumn{1}{l}{$-l-$} \\
\hline Nonisogenic & 4 weeks & $188(35 \%)$ & $331(61 \%)$ & $25(4.5 \%)$ \\
& born & $26(21 \%)$ & $69(56 \%)$ & $28(23 \%)$ \\
& live after & & & \\
& $4 \mathrm{hr}$ & $26(21 \%)$ & $69(56 \%)$ & $2(1.6 \%)$ \\
Isogenic & 4 weeks & 30 & 48 & 0 \\
$129 \mathrm{sv}$ & day l8.5 & 6 & 8 & 7 \\
\hline
\end{tabular}

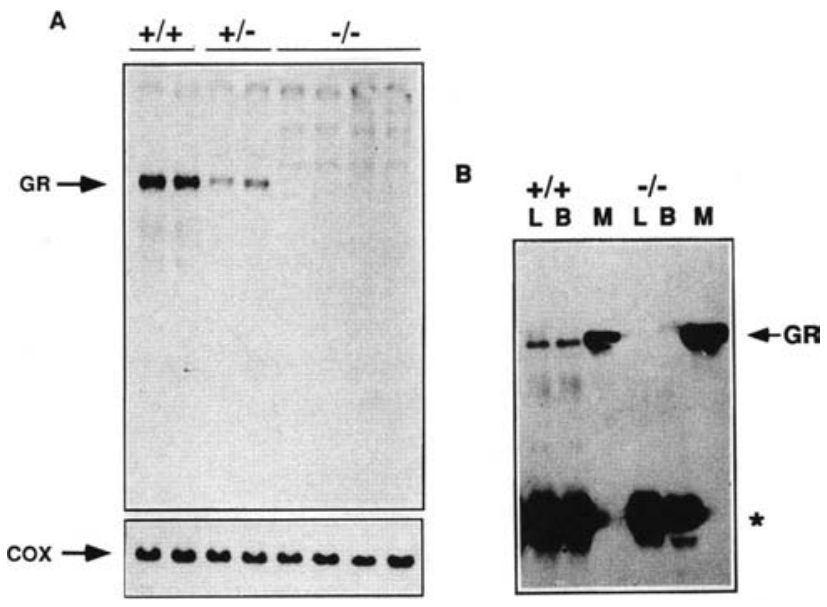

Figure 2. Analysis of expression of the GR gene in GR - /mice. (A) Northern blot analysis of GR mRNA in RNA from lung. Total RNA $(25 \mu \mathrm{g})$ was analyzed from wild-type $(+/+)$, heterozygous $(+1-1$, and homozygous mutant $(-1-)$ lung tissue. (GR) Glucocorticoid receptor. (COX) cytochrome oxidase. $(B)$ Western blot analysis of immunoprecipitates from nuclear extracts using a GR-specific polyclonal antibody. Nuclear extracts were prepared from liver (L) and brain (B) of wild-type $(+1+)$ and mutant $(-1-)$ adult animals. Baculovirus-expressed GR $(0.1 \mu \mathrm{g})$ was used as a control (lanes M). Cross-reacting heavy-chain IgG is indicated by an asterisk (*).

tected in lung RNA from GR $-/-$ mice. The presence of faint larger bands in RNA from -1 - mice indicated the possible existence of a small amount of potentially chimeric GR/PGKNEO transcripts. The presence of GR protein was analyzed in nuclear protein extracts from liver and brain of adult wild-type and surviving adult GR $-/-$ mice. Extracts were immunoprecipitated using a polyclonal GR-specific antibody and then analyzed by Western blotting (Fig. 2B). No GR protein was detected in extracts from GR $-/-$ mice, confirming the lack of GR protein in these animals.

\section{GR - / - mice display acute respiratory distress}

At birth, GR $-1-$ mice show respiratory distress and nearly all die within a few hours. A litter from an intercross of heterozygous animals delivered by Caesarean section at day 18.5 post coitum (p.c.) is depicted in Figure $3 \mathrm{~A}$ and shows two cyanotic offspring (arrows) with severe respiratory distress. To investigate the cause of impaired function of the lungs, histological analysis was performed on mice at birth as well as at earlier time points in development (Fig. 3). Comparison of a cross section through a newborn GR - / - mouse and a wildtype littermate (Fig. $3 \mathrm{~B}, \mathrm{C}$ ) indicates severe lung atelectasis in GR - / - animals. There is little or no inflation of lung tissue. Histological examination of lungs from different stages of development in GR $-/-$ (Fig. $3 \mathrm{H}-\mathrm{K}$ ) and wild-type embryos (Fig. 3D-G) shows that loss of glucocorticoid signaling via the GR appears to impair devel- 
opment of terminal bronchioles and alveoli from day 15.5 p.c.

The surfactant protein genes SP-A, SP-B, SP-C, and SP-D are activated in lung prior to birth by a number of hormones and growth factors, including glucocorticoids (Haagsman and van Golde 1991; Mendelson and Boggaram 1991). Preliminary in situ hybridization using probes for SP-B and SP-C show a similar spatial expression pattern in the developing epithelium of branching bronchioles and alveoli for both wild-type and GR - / lung (data not shown) and indicates that a relatively similar number of developing alveolar type II cells are present in GR - / - lungs. We also find little difference in the expression of the SP-A, SP-B, and SP-C genes in lung of GR - / - mice at birth by Northern blots using cDNA probes (data not shown).
Removal of fluid from the lung around birth is an important step prior to lung inflation (Bland and Nielson 1992). This process is dependent on increased $\mathrm{Na}^{+}$transport across the epithelium before birth via an amiloridesensitive $\mathrm{Na}^{+}$channel. This amiloride-sensitive $\mathrm{Na}^{+}$ channel gene in the rat is expressed in lung epithelium starting from about day 17 p.c. and is inducible by dexamethasone (Champigny et al. 1994). We therefore measured the expression of this gene by Northern blot analysis in lung RNA from newborn GR - / - mice (Fig. 4A). Analysis of four individuals indicates a reduction in the level of amiloride-sensitive $\mathrm{Na}^{+}$channel mRNA in total lung RNA, which could lead to a reduction in the capacity of epithelium $\mathrm{Na}^{+}$transport and, consequently, of water removal from the lungs before birth and contribute to atelectasis in mutant animals.

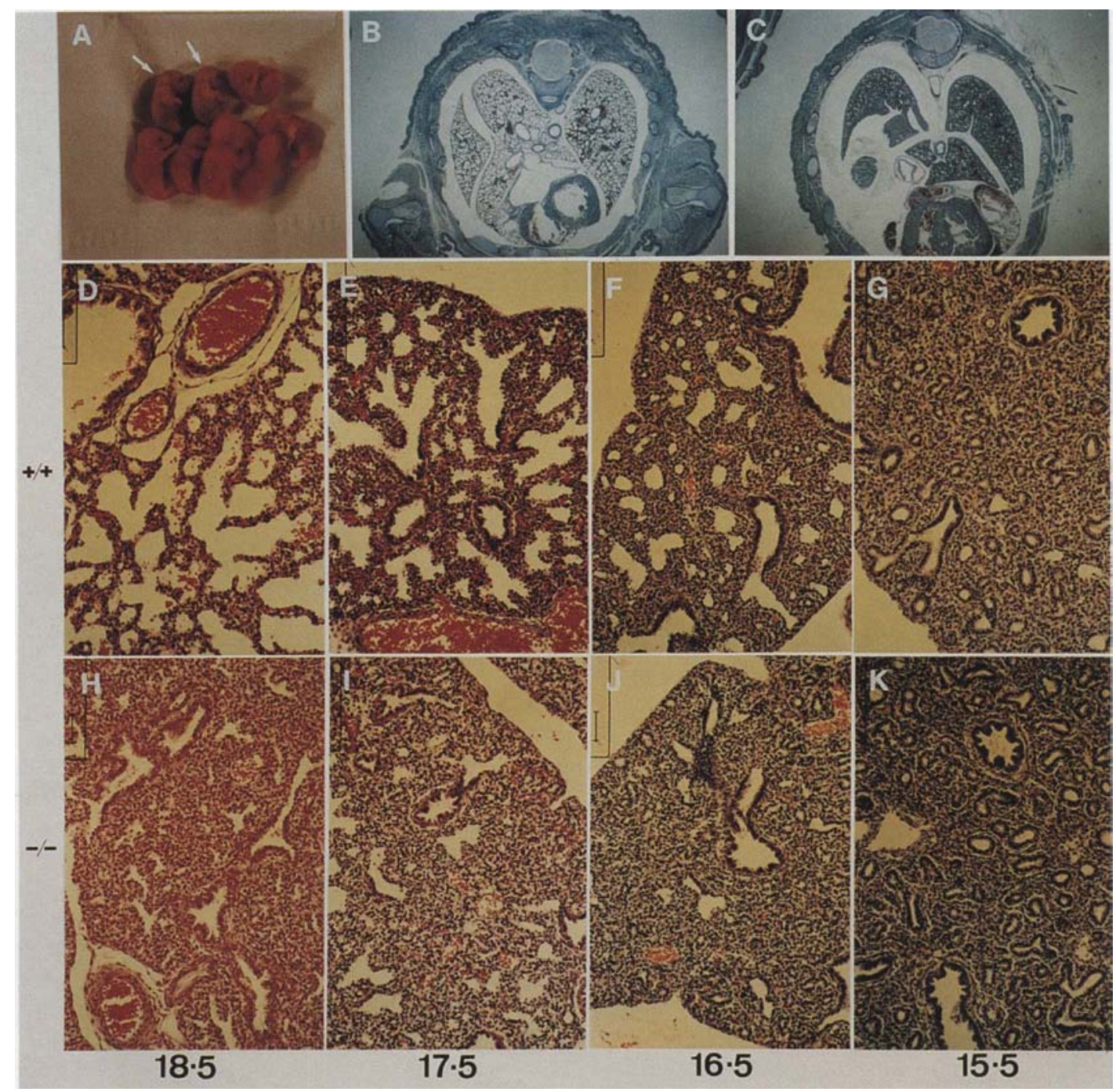

Figure 3. Histological analysis of lung from wild-type and GR - / - mice. (A) A litter of a GR heterozygote intercross delivered by Caesarean section at day 18.5 p.c. Two severely cyanotic pups are indicated by arrows. Cross section of a wild-type GR $(B)$ and GR $-/-(C)$ offspring at day 18.5 p.c. shortly after Caesarean delivery. Histological analysis of lung from wild-type and GR $-/-$ embryos at day $18.5(D,+/+; \mathrm{H},-/-)$, day $17.5(E,+/+; \mathrm{I},-/-)$, day $16.5(F,+/+; \mathrm{J},-/-)$ and day $15.5(G,+/+; K,-/-)$ p.c. Bar: $A-F$, $100 \mu \mathrm{m} ; D-G, 50 \mu \mathrm{m}$. 


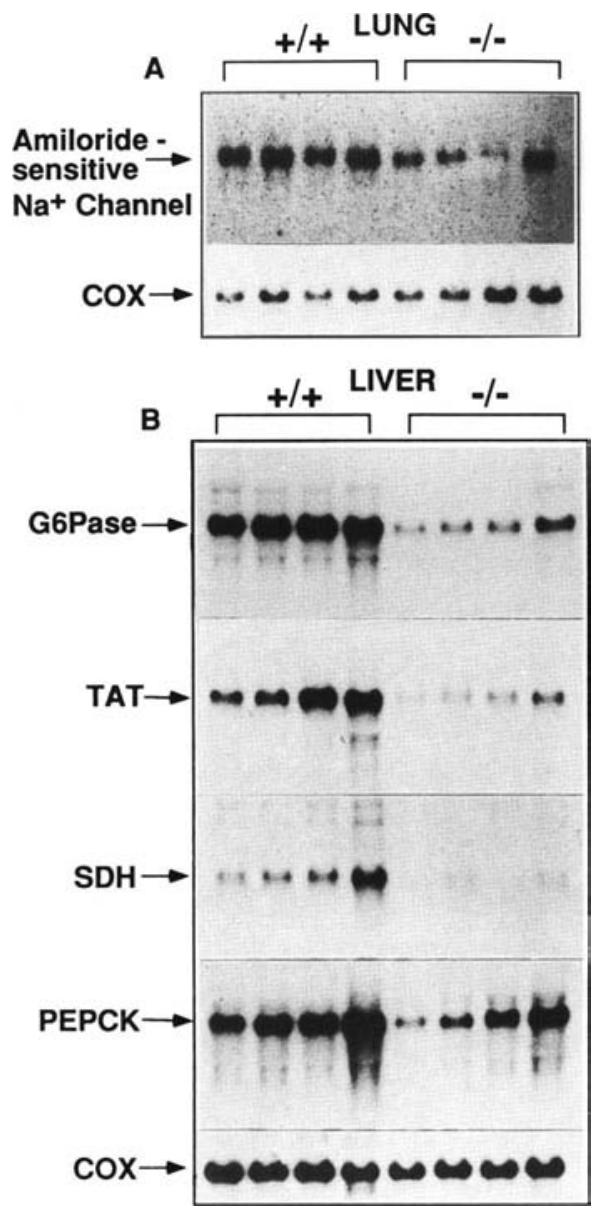

Figure 4. Northern blot analysis of RNA from lung and liver of GR wild-type and GR $-/-$ mice. $(A)$ Total RNA $(10 \mu \mathrm{g})$ from lung of newborn wild-type $(+1+1$ and GR mutant $(-1-)$ mice were analyzed with a rat amiloride-sensitive $\mathrm{Na}^{+}$channel cDNA. (B) Total RNA $(20 \mu \mathrm{g})$ from liver of newborn wild-type $1+1+\mid$ and GR mutant $\mid-1-1$ mice were analyzed with cDNA probes for G6Pase, TAT, SDH, and PEPCK. All filters were hybridized with a cDNA for mouse cytochrome oxidase (COX) to control for RNA loading.

GR - / - mice have impaired activation of hepatic gluconeogenic enzymes

Glucocorticoids and glucagon, the latter acting via cAMP, are implicated in the activation of genes encoding gluconeogenic enzymes during the perinatal period (Pilkis and Granner 1992). We therefore analyzed the level of expression of a number of these genes by Northern blot analysis in RNA prepared from newborn liver of wild-type and GR -/ - mice (Fig. 4B). G6Pase, a key gluconeogenic enzyme, showed a severe reduction in its mRNA levels in GR - / - newborn liver, indicating impaired activation around birth. RNA levels of the key regulatory enzyme PEPCK was also reduced, but not in all cases in liver RNA from GR - / - mice. Partial perinatal activation of PEPCK could be attributable to the action of other signaling pathways acting on the PEPCK gene such as the cAMP pathway or via stimulation by thyroid hormone (Imai et al. 1993). Tyrosine aminotransferase (TAT) and serine dehydratase (SDH) are two enzymes that help catabolize amino acids for import into the gluconeogenic pathway (Ogawa et al. 1988; Pilkis and Granner 1992). Activation of both genes is severely affected in liver of GR $-/-$ mice. Although the genes for gluconeogenic enzymes are regulated by glucocorticoids and the cAMP pathway (Lucas and Granner 1992; $\mathrm{Su}$ and Pitot 1992), cAMP signaling alone does not seem to be sufficient to significantly activate these genes perinatally. These observations underscore the importance of glucocorticoid signaling via the GR in the activation of perinatal gluconeogenesis.

\section{GR - / - mice have enlarged and disorganized} adrenal glands

Adrenal glands from GR - / - mice are approximately twice the size of those of wild-type littermates and display a number of altered features (Fig. 5A,B). The increase in size is attributable to a prominent hypertrophy and possible hyperplasia of adrenal cortical cells (Fig. 5, cf. A and B). These cortical cells, including their nuclei, are enlarged up to two- to threefold. Overall, adrenals of GR - / - mice are disorganized and contain no central medulla of chromaffin cells as seen in wild-type newborn adrenals. Histological analysis and electron microscopy (data not shown) of adrenal tissue from newborn GR - / - mice do, however, reveal the presence of a small number of chromaffin cells scattered among enlarged cells of the cortex (see below).

The adrenal cortex is composed of three zones. The outer zona glomerulosa synthesizes mineralocorticoids and the inner zona fasciculata and reticularis synthesizes glucocorticoids. To assess the formation of the normal adrenal cortical zones we analyzed adrenal sections at day 18.5 p.c. by in situ hybridization using cRNA probes specific for the steroid $11 \beta$-hydroxylase $\left(\mathrm{P} 40_{\mathrm{C} 11 \beta}\right)$ and aldosterone synthase (AS) genes (Fig. 5 E-H). These enzymes catalyze the final steps for corticosterone and aldosterone synthesis, respectively (Domalik et al. 1991). Hybridization for $\mathrm{P} 450_{\mathrm{C} 113}$ was detected over the entire cortex in newborn adrenals from both GR wild-type and -1 - mice, with stronger expression detected in GR - / - adrenals. Hybridization of the AS probe in adrenal glands was restricted to an outer layer of three or four cell diameters, corresponding to the zona glomerulosa, with much stronger signals consistently detected in GR $-/$ - adrenals (see below). These results indicate normal formation of the zona glomerulosa, with greatly enhanced expression of AS in GR mutants, and an expansion of the zona fasciculata/reticulata in GR - / - mutant adrenals.

Impaired glucocorticoid regulation via the HPA axis in $G R-/-$ mice

One factor controling glucocorticoid synthesis is feedback inhibition at the level of ACTH production and 
GR is required for adrenal and lung development
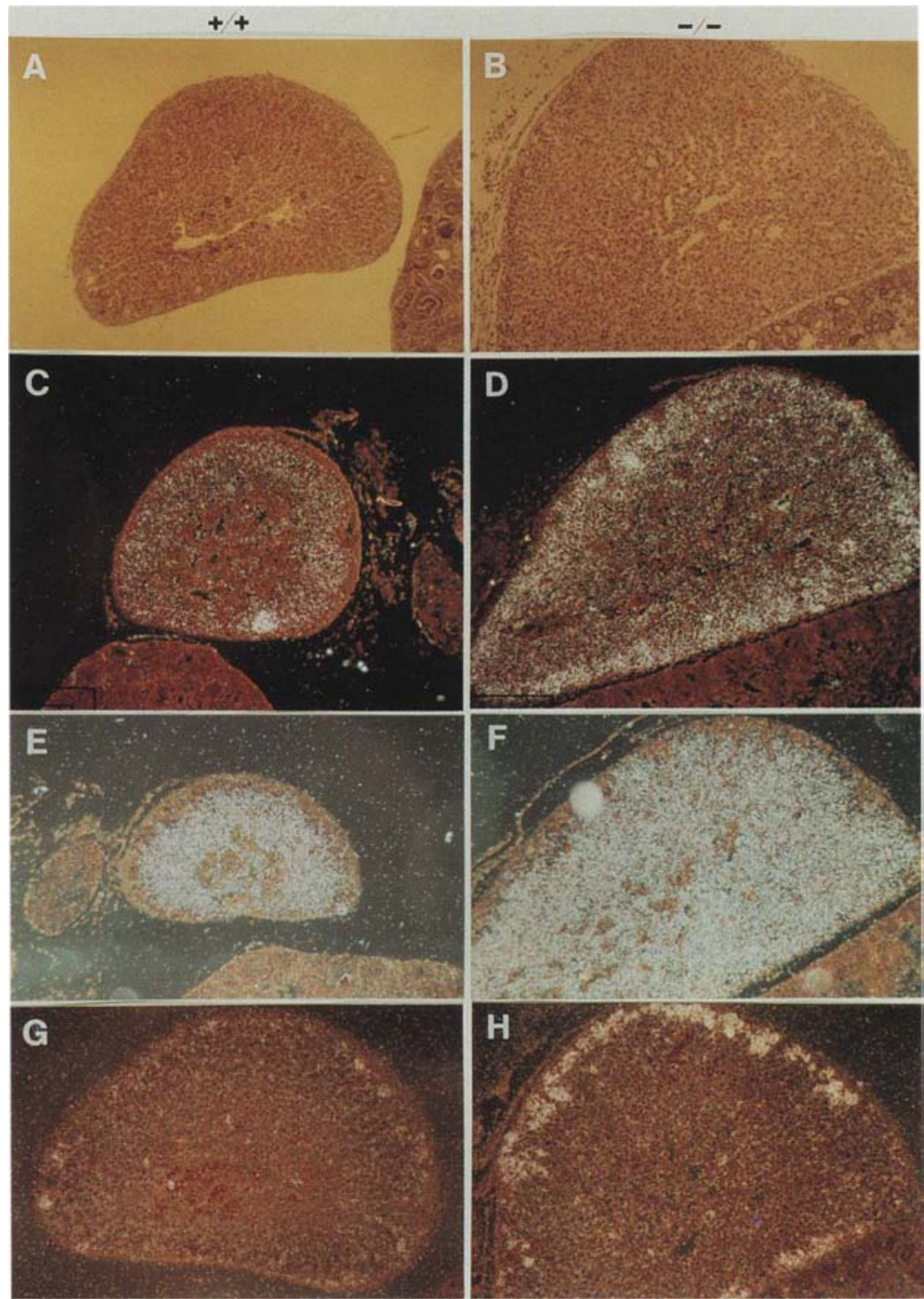

Figure 5. Histological analysis of adrenal glands from wild-type and GR - / - mice. Wild-type mice 18.5 days old $(A)$ and $G R-1-$ mice $(B)$ were sectioned and stained with eosin/hematoxylin. In situ hybridization (shown in dark field) was performed on sections from newborn adrenal glands of wild-type mice $(C, E, G)$ and $G R-1-$ mice $(D, F, H)$ using cRNA probes for mouse $\mathrm{P}_{450} \mathrm{SSC}$

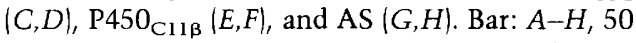
$\mu \mathrm{m}$. release from the anterior pituitary (Chrousos 1992). To assess function of the HPA axis, plasma levels of corticosterone and adrenocorticotropic hormone $(\mathrm{ACTH})$ were measured in wild-type, GR $+/-$, and GR $-/-$ newborn animals (Table 2). Total plasma corticosterone in GR - / - newborn mice was found to be elevated twoto threefold indicating an increased production and/or secretion of glucocorticoids. The circulating levels of ACTH were $>20$ times higher in GR $-/-$ animals. Apparently, because of the absence of the GR, feedback repression of ACTH synthesis via glucocorticoids is ineffective, resulting in a hypertrophy of the zona fasciculata/reticularis cortical cells with increased production of corticosterone. The synthesis of many steroid biosynthetic enzymes in the adrenal cortex is under the control of ACTH (Orth et al. 1992). We measured the level of expression by in situ hybridization of the side-chain cleavage enzyme $\left(\mathrm{P}_{450} 0_{\mathrm{Ssc}}\right), 21 \alpha$-hydroxylase $\left\{\mathrm{P} 40_{\mathrm{C} 21}\right)$,
P450 ${ }_{\mathrm{Cl1 \beta}}$, and AS (see above and Fig. 5). In the presence of higher circulating levels of $\mathrm{ACTH}$, expression of $\mathrm{P} 450_{\mathrm{SSC}}$ and $\mathrm{P}_{450_{\mathrm{C} 1 \beta} \beta}$ was found to be elevated by about two- to threefold. (Fig. 5C-F), and surprisingly, expression of AS in the zona glomerulosa was found to be greatly increased (Fig. $5 \mathrm{G}, \mathrm{H}$ ). Expression of $\mathrm{P}_{450_{\mathrm{C} 21}}$ was

Table 2. Corticosterone and adrencorticotrophic hormone levels in newborn GR mice

\begin{tabular}{|c|c|c|c|c|c|}
\hline $\begin{array}{l}\text { GR } \\
\text { genotype }\end{array}$ & $n$ & $\begin{array}{l}\text { Plasma } \\
\text { corticosterone } \\
\text { (ng/ml) }\end{array}$ & S.E. & $\begin{array}{l}\text { Plasma } \\
\text { ACTH } \\
(\mathrm{pg} / \mathrm{ml})\end{array}$ & S.E. \\
\hline$+1+$ & 12 & 75.4 & \pm 8.0 & 152 & \pm 23 \\
\hline$+1-$ & 22 & 135.8 & \pm 9.3 & 397 & \pm 54.5 \\
\hline$-1-$ & 15 & 183.2 & \pm 15.5 & 2270 & \pm 329 \\
\hline
\end{tabular}


unchanged (data not shown). Obviously, because of the hypertrophy of the adrenals the steroid biosynthetic capacity is greatly increased.

Interestingly in heterozygous newborn animals, containing only one functional copy of the GR gene, an elevation in the plasma levels of glucocorticoids and ACTH intermediate between the level of wild-type and GR - / - mice is apparent. Histological analysis of adrenal glands from GR - / - mice at earlier times during development show that the hypertrophy of adrenal cortical cells is already apparent by about day 15 p.c. of mouse development (Fig. 7B, below). This suggests an elevated circulating level of glucocorticoids in the mutant embryo and that the negative feedback regulation of glucocorticoids via the HPA axis may be operative from this stage in normal mouse development.

\section{Impaired development of chromaffin cells in the early fetal adrenal glands in GR - / - mice}

The major function of the chromaffin cells of the adrenal medulla is the synthesis and secretion of the catecholamines, adrenaline, and noradrenaline. Glucocorticoids are thought to play an important role in the development of neural crest-derived chromaffin cells from bipotential sympathoadrenal progenitors (Anderson 1993a). To analyze the effect of lack of GR on the adrenal medulla, adrenal sections were immunostained using the neuro- nal cell-specific marker, synaptophysin (Fig. 6A,B). Chromaffin cells are strongly stained and can be distinguished easily in wild-type mice as the central mass of cells that form the medulla. In adrenals of GR - / - mice we detect a small number of scattered cells. Sections were then analyzed for expression of tyrosine hydroxylase (TH), a key enzyme in catecholamine synthesis and an adrenal marker for the chromaffin cell. In GR - / - mice these small scattered clusters of cells were found to be positive for $\mathrm{TH}$, clearly demonstrating the presence of chromaffin cells (Fig. 6E,F). The majority of differentiated chromaffin cells $170 \%-80 \%$ in mice and termed adrenergic) synthesize adrenaline and express the enzyme phenylethanolamine $N$-methyltransferase (PNMT), which catalyzes the conversion of noradrenaline to adrenaline and is known to be regulated by glucocorticoids (Jiang et al. 1989). Expression of PNMT in newborn mice was analyzed by in situ hybridization (Fig. 6C,D). No expression of PNMT was detected in the synaptophysin and TH-positive cells of GR -/ - adrenals, which indicate that these cells are likely to represent noradrenergic chromaffin cells. To further characterize the functional properties of these cells, newborn adrenal glands were analyzed for catecholamine content using HPLC (Table 3). This showed that adrenal glands of GR $-/$ - mice contain no adrenaline, which is consistent with the lack of PNMT expression, and reduced amounts of noradrenaline. Interestingly, adrenal glands of hetero-
Figure 6. Analysis of the adrenal medulla in newborn wild-type and GR - / - mice. Sections of newborn adrenal gland from wild-type $(A)$ and GR $-/-(B)$ mice were immunostained for synaptophysin. In situ hybridization was performed on sections of newborn adrenal gland from wildtype $\{C\rangle$ and GR $-/-(D)$ mice using a cRNA probe for mouse PNMT (shown in dark field). Sections of newborn wild-type $(E)$ and GR $-/-(F)$ adrenal glands immunostained for TH. Scale Bar: $A$ and $B, 100 \mu \mathrm{m} ; C-F, 50 \mu \mathrm{m}$.

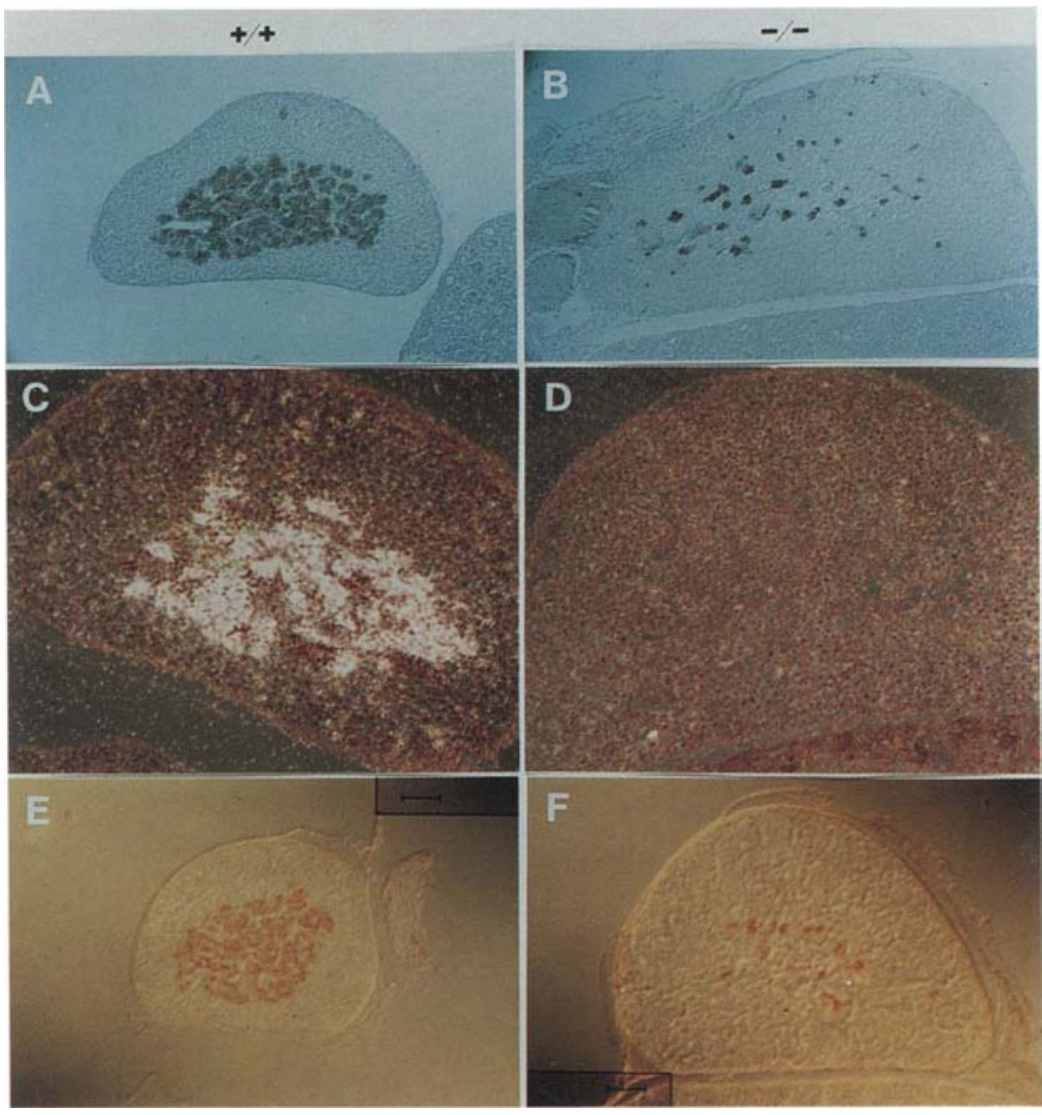


Table 3. Catecholamine levels in whole adrenal glands of newborn mice

\begin{tabular}{lcccc}
\hline Genotype & $n$ & $\begin{array}{l}\text { Noradrenaline } \\
\text { (ng/adrenal) }\end{array}$ & $\begin{array}{l}\text { Adrenaline } \\
\text { (ng/adrenal) }\end{array}$ & $\begin{array}{l}\text { Total } \\
\text { catecholamines } \\
\text { (ng/adrenal) }\end{array}$ \\
\hline$+/+$ & 3 & $7.60 \pm 0.55$ & $16.87 \pm 0.65$ & $24.47 \pm 0.23$ \\
$+/-$ & 7 & $7.78 \pm 0.78$ & $7.37 \pm 2.86$ & $15.15 \pm 2.93$ \\
$-/-$ & 7 & $2.56 \pm 1.12$ & N.D. & $2.56 \pm 1.12$ \\
\hline
\end{tabular}

(N.D.) Not detected by assay.

zygous mice contain approximately half of the amount of adrenaline compared to wild-type mice. Our results therefore indicate the presence of only noradrenalineproducing or noradrenergic chromaffin cells and the complete lack of adrenergic chromaffin cells in the adrenal glands of GR $-/-$ mice. The reduced amount of noradrenalin in adrenal glands of GR - / - mice is consistent with the absence of adrenergic chromaffin cells, as normally these cells produce small quantities of noradrenaline at birth.

To further investigate the lack of adrenergic chromaffin cells, adrenal glands from staged embryos were analyzed at 13.5 and 15.5 days p.c. of development (Fig. 7). Sections of adrenals were immunostained for $\mathrm{TH}$ to identify chromaffin precursor cells. As in newborns, a greatly reduced number of chromaffin cells was detected both at day 13.5 p.c. and 15.5 day p.c. of development in adrenal glands of GR $-/-$ embryos (Fig. 7F,H). These chromaffin cell progenitors also lacked expression of the PNMT gene, which was detected in equivalent sections of adrenal glands from wild-type littermates by in situ hybridization (data not shown). The GR is therefore not only required for inducing correct expression of PNMT in normal differentiating chromaffin cells but is required for proliferation and/or survival of a majority of chromaffin cells from an early stage. Only a small subset of chromaffin cells synthesizing noradrenaline survive and proliferate in the absence of glucocorticoid signaling via the GR.

A small number of GR $-/-$ mice survive to adulthood, indicating an incomplete penetrance of the phenotype. The reason for this remains unknown but probably relates to genetic background variations between individual animals. The adrenal glands of surviving GR - / - adult mice lack a normal central medulla region that is replaced by a mass of white adipose and loose highly vascularized connective tissue (data not shown). This disorganized central region does contain small clumps of TH-positive chromaffin cells that lack expression of the PNMT gene (data not shown). The differentiation of the medulla into fully adrenergic and noradrenergic chromaffin cells takes place a few weeks after birth. Therefore, an electron microscopic analysis was performed on adult adrenal glands and showed the presence of only noradrenaline-specific chromaffin granules in these TH-positive chromaffin cells compared with the wild-type adrenal medulla where chromaffin cells with adrenaline-specific chromaffin granules are seen as well (Fig. 8A,B). The adult adrenal glands lack adrenergic chromaffin cells, which normally make up $75 \%$ of the adult mouse adrenal medulla (Coupland 1965), and have a similar phenotype to that of GR $-/-$ mice at birth.

\section{Discussion}

We have investigated the role of the GR in mouse embryonic development by gene targeting and found several striking defects in GR-deficient animals. Disruption of

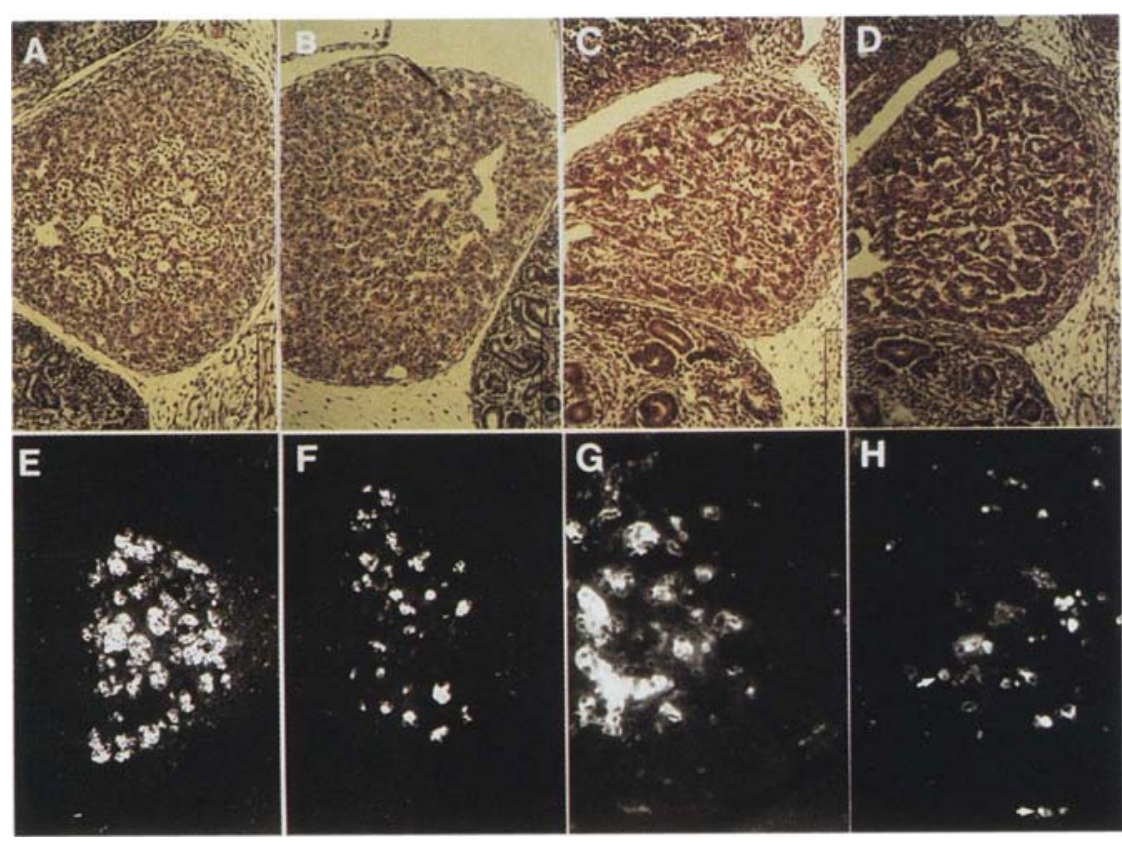

Figure 7. Lack of adrenergic chromaffin cell development in the adrenal of GR $-/$ - mice. Embryos from staged pregnancies were genotyped and sagittal sections stained with eosin/hemotoxylin $(A, D)$ or immunostained for $\mathrm{TH}(E-H)$. Adrenal glands of wild-type and GR $-/$ - embryos are shown from day 15.5 p.c. ( $A$ and $E$, wild type; $B$ and $F, \mathrm{GR}-/-1$ and day 13.5 p.c. $(C$ and $G$, wild type; $D$ and $H$, GR $-/-$ ). Arrows indicate nonspecifically stained erythrocytes. Bar: $A-F, 50 \mu \mathrm{m} ; G$ and $H, 25$ $\mu \mathrm{m}$. 


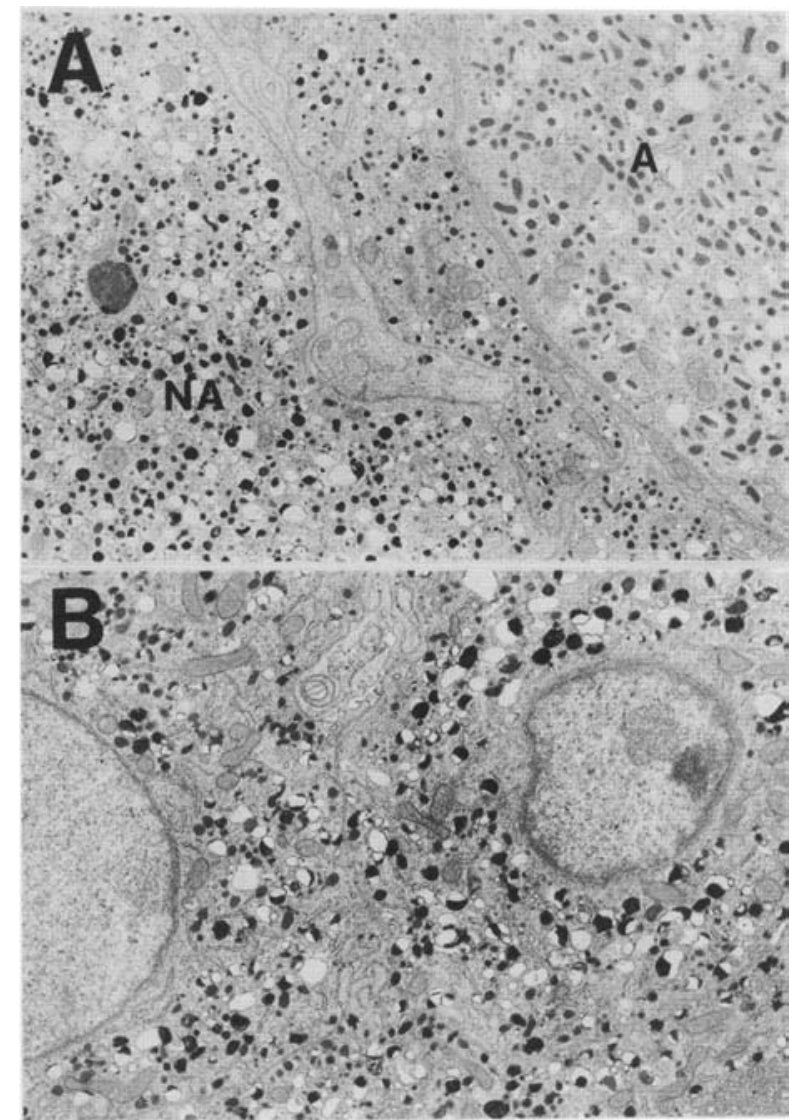

Figure 8. Analysis of adrenal chromaffin cells from surviving adult GR $-/$ - mice by electron microscopy. Electron micrographs of the adrenal medulla from adult wild-type $(A)$ and GR $-/-(B)$ mice showing chromaffin cells with adrenaline-containing $(A)$ adrenaline or noradrenaline-containing (NA) noradrenaline chromaffin granules.

the GR gene in vivo demonstrates the requirement of glucocorticoid signaling in mouse development from approximately day 14 p.c. GR $-/-$ mice at birth show developmental defects in the lung, adrenal cortex, and medulla and display defective liver and HPA axis functions. This GR mutation shows incomplete penetrance, a feature also seen with some other targeted genes (Johnson et al. 1992; Klein et al. 1993; Lufkin et al. 1993). Prelimenary data suggest that placing this GR mutation into the $129 / \mathrm{J}$ isogenic mouse strain background produces a fully penetrant phenotype (see Table 1). From 78 offspring, we have found no surviving GR $-/$ - mice so far. Analysis of three isogenic litters at birth (Table 1) showed the same phenotype of atelectatic lungs and enlarged disorganized adrenal glands in GR - / - mutants (data not shown).

Although not studied in detail, the small number of GR - / - mice surviving after birth also display a number of defects. Their adrenal glands have a disorganized medulla with a strong reduction in the number of chromaffin cells. The few random clumps of chromaffin cells are noradrenergic and do not express PNMT (data not shown). Circulating levels of glucocorticoids and ACTH are elevated but seem to follow a normal circadian cycle (data not shown). Although we find no differences between wild-type and GR $-/$ - animals in thymus histology or in circulating $\mathrm{T}$-cell numbers, thymocytes from newborn and adult GR - / - mice are totally resistant to dexamethasone-induced apoptosis (F. Flomerfelt and $\mathrm{T}$. Cole, in prep.). These animals will be extremely useful for investigating the physiological role of GR in glucocorticoid signaling with respect to immunosuppression, the inflammatory response, the stress response, and studies on behavior control.

\section{Glucocorticoids are critical for lung maturation}

Severe asphyxia is observed in most GR $-/$ - mice and is the likely cause of early postnatal death. Histological analysis of the lungs of GR - / - mice indicates atelectasis and a lack of normal development. In mice, lung development begins with the formation of the lung buds from the endoderm foregut at about day 10.5 p.c. and proceeds with a progression of proliferation, branching, and differentiation of lung epithelium. This gives rise to two types of epithelial cells, the alveolar type 1 and type 2 cells, the latter of which synthesize surfactant. Glucocorticoids are one of a number of hormones and growth factors, including prolactin, thyroid hormone, estrogens, insulin, and catecholamines implicated in lung development (Haagsman and van Golde 1991). Application of glucocorticoids in vivo is known to accelerate lung maturation and surfactant synthesis, and is used clinically in premature infants with respiratory distress syndrome (Ballard 1986).

Little is known about the time when different hormones and growth factors are required for lung development in vivo. Our results indicate that glucocorticoid signaling via the GR is critical for lung function and development from approximately day 15.5 p.c. The lack of airway expansion at birth indicates a possible defect in epithelial cell functions. We find similar numbers of alveolar type II cells and, by in situ hybridization, little difference in expression of two type II cell markers, SP-B and SP-C, both of which are thought to be partially regulated by glucocorticoids. We have also found little difference in the steady-state RNA levels by Northern analysis of the SP-A, SP-B, and SP-C genes in lung at birth in GR $-/$ - mice, but this does not exclude that expression of other surfactant-related genes may be affected. Production of lung surfactant may still be affected in GR - / - mice, as glucocorticoids are able to modulate expression of many other surfactant-related genes, at least in vitro (Mendelson and Boggaram 1991). Glucocorticoids, for example, stimulate synthesis of phosphatidylcholine, the major lipid component of surfactant, by increasing the activity of key lipogenic enzymes such as CTP/choline phosphate cytidylyltransferase (Mallampalli et al. 1994). We have shown a reduced expression of the amiloride-sensitive $\mathrm{Na}^{+}$channel gene in lungs of GR 
$-/-$ mice at birth. This gene is specifically expressed in alveolar type 2 epithelial cells, and reduced expression could result in the insufficient removal of fluid from newborn lungs and contribute to the lack of normal lung inflation (Champigny et al. 1994). Although catecholamines are not totally absent from the adrenal glands of GR - / - mice, the total lack of adrenaline may additionally contribute to impaired lung development. The release of adrenomedullary catecholamines has been implicated as being an important factor for survival through the perinatal period (Slotkin and Seidler 1988). It is interesting to note that all offspring from matings of mice homozygous for a disrupted corticotrophin-releasing hormone ( $\mathrm{CRH}$ ) gene display a similar alteration in lung maturation, and all die hours after birth, whereas homozygous offspring from heterozygous matings survive (Muglia et al. 1995). These CRH-deficient mice have very low circulating levels of glucocorticoids, which indicates the importance for glucocorticoids for lung maturation around birth. Interestingly, offspring of CRH $-1-$ matings have a $50 \%$ decrease in SP-B expression in the lung at birth. A more detailed analysis of surfactant production in GR $-/$ - mice during lung development is in progress.

\section{Lack of induction of key liver gluconeogenic enzymes}

Expression of G6Pase, PEPCK, TAT, and SDH, enzymes important for gluconeogenesis, which are known to be regulated by glucocorticoids, were examined in GR - / mice. Greatly reduced mRNA levels for G6Pase, TAT, and SDH were found in liver at birth, indicating a strong requirement for glucocorticoid signaling for their perinatal activation. Other pathways, such as those utilizing cAMP intracellular signaling, also operational around birth, were unable to fully activate the expression of these genes perinatally in liver of GR $-/-$ mice. Activation of the TAT gene has been well studied and is controlled by at least two upstream enhancers, one responding to CAMP and the other responding to glucocorticoids (Jantzen et al. 1987; Boshart et al. 1990). Our results indicate a critical importance for the glucocorticoid-dependent enhancer for perinatal activation of the TAT gene in liver. The control regions of the G6Pase gene have not yet been characterized, and our results would predict the presence of a strong glucocorticoidresponsive enhancer (GRE) controlling perinatal activation of this gene as well. Expression of the PEPCK gene was well induced in liver of some GR $-/-$ newborn mice. The PEPCK gene is regulated by two complex enhancers, a distal composite GRE, and a proximal cAMPresponsive enhancer (CRE) (Imai et al. 1993), the latter of which seems able, in at least some animals, to provide sufficient activation of PEPCK expression in liver at birth. The observation that activation of gluconeogenic enzymes is strongly but not completely reduced complements our previous studies in transgenic mice, which showed that both the GRE and CRE can mediate perinatal activation (Montoliu et al. 1995).

\section{Disrupted regulation of adrenal glucocorticoid production via the HPA axis}

Glucocorticoids control their own production via the HPA axis, where they negatively regulate expression of the pro-opiomelanocortin gene (POMC; the precursor protein for ACTH) in the anterior pituitary and corticotrophin-releasing factor (CRF) gene in the hypothalamus (Chrousos 1992). The increased plasma glucocorticoid and ACTH levels in GR - / - mice indicate a breakdown in the regulation of glucocorticoid production in the adrenal cortex. The very high plasma levels of ACTH are indicative of little or no feedback repression by glucocorticoids on ACTH production. We also expect a similar effect on CRF production in the hypothalamus. Glucocorticoids acting via GR therefore seem to be directly involved in the regulation of POMC, and possibly CRF, expression in the brain. This is consistent with the characterization of a negative GRE in the mouse POMC gene control region (Drouin et al. 1993). A consequence of high levels of ACTH is the increased expression of $\mathrm{P} 450_{\mathrm{SsC}}$ and $\mathrm{P} 450_{\mathrm{C} 11 \beta}$ and the very high expression of AS in the adrenal zona glomerulosa, which could result in increased levels of circulating aldosterone in the blood. The hypertophy of adrenal cortical cells is most likely a direct consequence of high ACTH levels and is a characteristic also seen in patients with pituitary tumours overproducing ACTH (Orth et al. 1992). Interestingly, we see similar hypertrophy in adrenal cortical cells as early as day 15.5 p.c. of mouse development, suggesting that the HPA axis may be actively controling glucocorticoid production well before birth.

\section{Glucocorticoids are critical for appearance of adrenergic but not noradrenergic chromaffin cells}

In mammals, neural crest cells migrate from between somite 18-24 of the dorsal neural tube to give rise to the neurons of the enteric and sympathetic ganglia, and to adrenal chromaffin cells (Patterson 1990; Anderson 1993a). Sympathoadrenal progenitors isolated from fetal adrenal glands are bipotential when cultured in vitro. In the presence of nerve growth factor they differentiate to form sympathetic neurons, and in the presence of glucocorticoids they form chromaffin-like cells (Anderson and Axel 1986). From in vitro experiments of early sympathoadrenal progenitors a simple model has been postulated that chromaffin cell differentiation and proliferation in vivo require glucocorticoid signals at two different stages in development, an early signal to initiate differentiation of the chromaffin cell lineage and a later signal to activate the chromaffin cell-specific gene expression program, exemplified by the induction of the PNMT gene (Michelsohn and Anderson 1992).

This bipotential progenitor model was recently modified after the generation of MASH-1-deficient mice by gene targeting (Guillemot et al. 1993). MASH-1 is a neural-specific basic-helix-loop-helix protein and is expressed broadly in the developing central and peripheral nervous system (Guillemot and Joyner 1993). MASH-1 
expression is not detected in early migrating neural crest cells but is first detected at day 10.5-11.5 in progenitor cells, which give rise to cells condensing in the sympathetic, parasympathetic, and enteric ganglia. These progenitors are thought to also give rise to the adrenal chromaffin cells. MASH-1 - / - mice lack development of sympathetic ganglia, but surprisingly, there is only a weak effect on chromaffin cell development with only a reduced number of $\mathrm{TH}$ and PNMT positive-chromaffin cells in the newborn adrenal gland. This argues that chromaffin cell and sympathetic neuron precursors may develop from an earlier MASH-1-independent type of bipotential progenitor cell and indicates that MASH-1 probably contributes to, but is not critical for, chromaffin cell development, which is thought to be dependent on glucocorticoids (Anderson 1993b). Surprisingly, in GR $-/-$ mice, not only is the capacity of chromaffin cells to synthesize adrenaline abolished, but the number of chromaffin cells are reduced substantially. This effect on the survival and/or proliferation of chromaffin cells must begin to occur quite early, because at day 13.5 p.c., shortly after precursor cells have migrated to the adrenal primordia, numbers of TH-positive cells in GR - / mice are already reduced in comparison to wild-type controls. Thus, a reasonable explanation for these observations might be that there is reduced survival/proliferation of a common chromaffin progenitor from about day 13.5 p.c. of mouse development. The few surviving chromaffin cells (which escape) in the GR - / - adrenal develop to be noradrenergic in nature because of their inability to switch on GR-dependent PNMT expression. Alternatively, the survival of an apparently normal number of noradrenergic chromaffin cells may be the result of their complete independence from GR-mediated survival and differentiation, suggesting an earlier separation than hitherto believed of committed noradrenergic from adrenergic chromaffin progenitors in the neural crest. This may be consistent with a recent study in the rat adult adrenal gland, which has shown high expression of GR in PNMT-positive (adrenergic) chromaffin cells but low expression in noradrenergic cells /Ceccatelli et al. 1989). Normal development of noradrenergic chromaffin cells in GR - / - mice but absence of adrenergic chromaffin cells may be the result of this differential expression and might suggest further the existence of two different cell populations that give rise to the mature adrenal medulla.

\section{Materials and methods}

\section{Construction of targeting vector}

Genomic clones from isogenic DNA containing the $5^{\prime}$ end of the mouse GR gene were obtained by screening an amplified mouse 129/Sv-C-P Sl/ + library in $\lambda$ GEM-12 (Promega) kindly provided by Anton Berns (Netherlands Cancer Institute, Amsterdam) using an exon 2-specific SalI-HindIII fragment (position +419 to $+935 \mathrm{bp}$; Strähle et al. 1992 ) as a probe. A $5.5-\mathrm{kb}$ HindIII fragment subcloned in pBluescript (Strategene), containing exons 1B, 1C, and 2 of the mouse GR gene, was used for construction of the targeting vector. A neomycin resistance gene cassette of $1.8 \mathrm{~kb}$, driven by the mouse PGK promoter, was inserted into a Tth $111 \mathrm{I}$ restriction site 40 nucleotides downstream from the GR AUG translation start in exon 2 . The final targeting vector was linearized with $\mathrm{XbaI}$ for electroporation.

\section{Culturing of ES cells and generation of $G R-/-$ mice}

The E14 ES cell line, maintained on mouse embryonic feeders, was kindly provided Klaus Rajewsky (Institute for Genetics of the University of Cologne, Germany). Twenty micrograms of $X b a I$-digested targeting vector DNA was used to electroporate $1 \times 10^{7}$ E14 ES cells. Genomic DNAs from cell clones surviving G418 selection $(200 \mathrm{mg} / \mathrm{ml})$ were subjected to Southern blot analysis. A 1.4-kb HindIII fragment located $3^{\prime}$ of the targeting vector homology was used as a $3^{\prime}$ external probe for Southern analysis on DNA digested with BglII. Positively targeted clones were confirmed using a $5^{\prime} 0.5-\mathrm{kb}$ EcoRI-HindIII fragment probe on genomic DNA digested with EcoRI. ES cells from three clones were used for injection into blastocysts derived from C57BL/6 mice. Blastocysts were transferred to pseudopregnant NMRI/Han females, and chimeric offspring were detected by the presence of agouti hairs (genotype $A^{w}$ ) on a nonagouti (a) background. Chimeric males were mated to females to produce ES cell-derived offspring that were then analyzed by Southern blot analysis on DNA isolated from tails. Mice heterozygous for the gene targeting event were then used in intercrosses to generate mutant GR $-/$ - mice.

\section{RNA and protein analysis}

Total RNA was prepared from various tissues and cell lines as described by LeMeur et al. (1981) RNA was separated in formaldehyde-containing agarose gels for Northern analysis as described by Sambrook et al. (1989). GeneScreen plus filters (Dupont) were hybridized in $50 \%$ formamide, $5 \times$ SSC, $50 \mathrm{~mm}$ $\mathrm{NaPO}_{4}$ at pH 6.5, $8 \times$ Denhardt's solution, $1 \%$ SDS, and 0.5 $\mathrm{mg} / \mathrm{ml}$ of total yeast RNA according to Ruppert et al. (1990), with in vitro-transcribed RNA probes. RNA probes for mouse TAT, PEPCK, and G6Pase and rat SDH were as described in Ruppert et al. (1990). A random-primed probe for the amiloridesensitive $\mathrm{Na}^{+}$channel gene was derived from a rat amiloridesensitive $\mathrm{Na}^{+}$channel cDNA kindly provided by Pascal Barbry (Institute of Molecular and Cellular Pharmacology, Valbonne, France). The cytochrome oxidase RNA probe was derived from a 95-bp AluI-HaeIII fragment of the mouse mitochondrial cytochrome oxidase gene (Murphy et al. 1983). Antibodies directed against the mouse GR receptor were generated by expression of the ligand-binding domain (amino acids 505-755, Danielsen et al. 1986) in Escherichia coli using the R-SET expression system (Invitrogen, San Diego) and then injection of the purified epitope into rabbits. Antibodies were purified by affinity chromatography. Nuclear extracts were prepared from liver and brain from wild type and GR $-/$ - mice by centrifugation of the tissue homogenates through $2.2 \mathrm{M}$ sucrose according to Gorski et al. (1986) and extraction of the nuclear fraction with radioimmunoprecipitation assay (RIPA) buffer containing $0.1 \%$ SDS. Proteins $(20 \mu \mathrm{g})$ were separated on $8 \%$ SDS-polyacrylamide gels, transferred to nitrocellulose filters, and immunostained with the affinity-purified anti-GR antibody using the ECL system from Amersham-Buchler (Braunschweig, Germanyl.

\section{Histological analysis and immunohistochemistry}

Tissues or whole embryos were fixed overnight in $4 \%$ buffered paraformaldehyde and paraffin-embedded, and sections of $5 \mu \mathrm{m}$ 
were stained using eosin and hemotoxylin. For immunohistochemical analysis, tissues were fixed as described and cut in sections of $4 \mu \mathrm{m}$ nominal thickness. Immunocytochemistry for synaptophysin was performed using a commercial rabbit antisenum (DAKO, Copenhagen). Synaptophysin immunoreactivity was detected using the avidin-biotin complex detection system. To visualize TH-positive chromaffin and chromaffin progenitor cells, sections from paraffin-embedded whole embryos or dissected tissues were stained with a mouse monoclonal antibody to rat TR $\left(1: 200,1 \mathrm{hr}\right.$ at $37^{\circ} \mathrm{C}$; Boehringer Mannheim) followed by incubation with $\mathrm{Cy} 3$ anti-mouse IgG (Dianova, Hamburg).

\section{In situ hybridization}

Mouse tissues and embryos were obtained from matings between GR heterozygous $(+1-1$ mice. Day 0.5 was assumed to begin at noon on the day the vaginal plug was observed. Tissues were fixed in $4 \%$ paraformaldehyde $(\mathrm{pH} 7.2)$ overnight, dehydrated through an ethanol series, cleared in toluene, and embedded in paraffin. Five-micron sections were cut for each tissue. In situ prehybridizations and hybridizations were carried out as described in Wilkinson (1992), using ${ }^{35}$ S-labeled cRNA probes. Slides were dipped in Kodak NTB2 emulsion diluted 1:1 with water and exposed at $4^{\circ} \mathrm{C}$ for 5-7 days and developed using Kodak D19 developing solution and Kodakfix at $15^{\circ} \mathrm{C}$ for $4 \mathrm{~min}$. Sections were stained using eosin and hematoxylin and visualized with a Zeiss Axiophot microscope.

\section{Electron microscopy}

For electron microscopy, embryonic day 18.5 and adult wildtype mice and GR $-/-$ mice were perfused through the left ventricle of the heart with a mixture of glutaraldehyde $(1.5 \%)$, paraformaldehyde $(1.5 \%)$, and polyvinylpyrrolidone (PVP; $2.5 \%$ ) in phosphate buffer at $\mathrm{pH}$ 7.3. Following perfusion, adrenal glands were immersed in the same fixative without PVP for 12-72 $\mathrm{hr}$ and then rinsed thoroughly in several changes of cacodylate buffer $(0.1 \mathrm{M})$. Organs were postfixed in $1 \% \mathrm{OsO}_{4}, 1.5 \%$ potassium hexanoferrate, rinsed in cacodylate, and $0.2 \mathrm{M}$ sodium maleate buffers (pH 6.0), and block-stained with $1 \%$ uranyl acetate. Following dehydration through a graded series of ethanol, tissues were embedded in Epon.

\section{Hormone measurements}

Plasma corticosterone was measured from $2 \mu$ l of plasma using a modified method of Gomez-Sanchez et al. (1975). Samples were diluted $1: 10$ in water, then $1: 10$ in methanol, and evaporated overnight at room temperature. Samples were then measured by radioimmunoassay (RIA) using anti-corticosterone antisenum (C8784, Sigma) and ${ }^{3} \mathrm{H}$-labeled corticosterone (TRK 406, Amersham). Samples were resuspended in $100 \mu \mathrm{l}$ of RIA buffer $0.05 \mathrm{M}$ Tris- $\mathrm{HCl}$ at $\mathrm{pH} 8,0.1 \mathrm{M} \mathrm{NaCl}, 0.1 \% \mathrm{NaN}_{3}, 0.1 \%$ BSA\}, and $100 \mu \mathrm{l}$ of anti-corticosterone antiserum diluted 1:4 in RIA buffer was added. Reconstituted protein A (100 $\mu$ l) (RPN 143, Amersham) was added, samples were allowed to incubate overnight, and then they were counted. A standard curve was included containing $0.01-5 \mathrm{ng} / \mathrm{ml}$ of corticosterone. Plasma ACTH was measured by RIA, as described by Nicholson et al. (1984). Human ACTH (AFP-2938C) and human ACTH-antiserum (AFP6328031) were kind gifts from the National Institute of Diabetes, Digestion, and Kidney disease (NIDDK) and the National Hormone and Pituitary Program, University of Maryland School of Medicine (Baltimore, MD). ${ }^{125} \mathrm{I}$-Labeled ACTH (IM216) was from Amersham. Catecholamines (adrenaline and noradrenaline) of newborn adrenal glands were quantified by high performance liquid chromatography (Beckman HPLC; Munich, Germany) and electrochemical detection (Chromosystems, Munich, Germany) essentially as described by Müller and Unsicker (1981).

\section{Acknowledgments}

We thank Dr. Gavin Kelsey and Dr. A. Francis Stewart for critically reading this manuscript and Dr. Klaus Kaestner for useful discussions and providing a mouse $129 / \mathrm{J}$ isogenic genomic library. The mouse PNMT gene was kindly provided by Richard Palmiter (University of Washington, Seattle), probes for mouse $\mathrm{P}^{4} 50_{\mathrm{SSC}}$, steroid $11 \beta$-hydroxylase, and AS were kindly provided by Keith Parker (Duke University Medical Center, Durham, $\mathrm{NC}$, probes for mouse SP-A and SP-C were provided by Jeffrey A. Whitsett (Children's Hospital, Cincinnati, $\mathrm{OH}$ ) and a probe for rat SP-B was provided by James $\mathrm{H}$. Fisher (University of Colorado, Denver). We are grateful to Erika Schmid, Daniela Klewe-Nebenius, Evelyn Grau, Dagmar Bock and Barbara Brühl for expert technical assistance, and Werner Fleischer for photographic art work. This work was supported by the Deutsche Forschungsgemeinschaft through SFB 229, the Leibniz program, and the Fonds der Chemischen Industrie.

The publication costs of this article were defrayed in part by payment of page charges. This article must therefore be hereby marked "advertisement" in accordance with 18 USC section 1734 solely to indicate this fact.

\section{References}

Anderson, D.J. 1993a. Molecular control of cell fate in the neural crest: The sympathoadrenal lineage. Annu. Rev. Neurosci. 16: 129-158.

1993b. MASH genes and the logic of neural crest cell lineage diversification. C.R. Acad. Sci. Paris 316: 1090 1096.

Anderson, D.J. and R. Axel. 1986. A bipotent neuroendocrine precursor whose choice of cell fate is determined by NGF and glucocorticoids. Cell 47: 1079-1090.

Arriza, J.L., C. Weinberger, G. Cerelli, T.M. Glaser, B.L. Hendelin, D.E. Houseman, and R.M. Evans. 1987. Cloning of the human mineralocorticoid receptor complementary cDNA: Structural and functional kinship with the glucocorticoid receptor. Science 237: 268-274.

Ballard, P.L. 1986. Hormones and lung maturation. In Monographs in endocrinology (ed. F. Gross, M.M. Grumbach, A. Labhart, M.B. Lipsett, T. Mann, L.T. Samuals, and J. Zander), Vol 28, pp. 1-354. Springer Verlag, Berlin, Germany.

Beato, M. 1989. Gene regulation by steroid hormones. Cell 56: 335-344.

Bland, R.D. and D.W. Nielson. 1992. Developmental changes in lung epithelial ion transport and liquid movement. Annu. Rev. Physiol. 54: 373-394.

Boshart, M., F. Weih, A. Schmidt, R.E.K. Fournier, and G. Schütz. 1990. A cyclic AMP response element mediates repression of tyrosine aminotransferase gene transcription by the tissue-specific extinguisher locus Tse-1. Cell 61: 905916.

Brody, J.S. and M.C. Williams. 1992. Pulmonary alveolar epithelial cell differentiation. Annu. Rev. Physiol. 54: 351-371.

Ceccatelli, S., A. Dagerlind, M. Schalling, A.-C. Wikstrom, S. Okret, J.A. Gustafsson, M. Goldstein, and T. Hökfelt, T. 1989. The glucocorticoid receptor in the adrenal gland is localized to the cytoplasm of adrenaline cells. Acta. Physiol. Scand. 137: 559-560. 
Champigny, G., N. Voilley, E. Lingueglia, V. Friend, P. Barbry, and M. Lazdunski. 1994. Regulation of expression of the lung amiloride-sensitive $\mathrm{Na}+$ channel by steroid hormones. EMBO I. 13: 2177-2181.

Chrousos, G.P. 1992. Regulation and disregulation of the hypothalamic-pituitary-adrenal axis. Endocrinol. Metab. Clin. North. Am. 21: 833-858.

Clark, J.H., W.T. Schrader, and B.W. O'Malley. 1992. Mechanism of action of steroid hormones. In Williams textbook of endocrinology, 8th Ed. (ed. J.D. Wilson and D.W. Foster), Vol. 3, pp. 35-90. Saunders, London, UK.

Coupland, R.E. 1965. The natural history of the chromaffin cell. pp. 250-251. Longmans Press, Edinburgh, UK.

Danielsen M., J.P. Nothrop, and G.M. Ringold. 1986. The mouse glucocorticoid receptor: Mapping of functional domains by cloning, sequencing, and expression of wild-type and mutant receptor proteins. EMBO I. 5: 3513-3522.

de Kloet, E.R., M.S. Oitzl, and M. Joels. 1993. Functional implications of brain corticosteroid receptor diversity. Cell. Mol. Neurobiol. 13: 433-455.

Domalik, L.J., D.D. Chaplin, M.S. Kirkman, R.C. Wu, W. Liu, T.A. Howard, M.F. Seldin, and K.L. Parker. 1991. Different isoenzymes of mouse $11 \beta$-hydroxylase produce mineralocorticoids and glucocorticoids. Mol. Endocrinol. 5: 1853-1861.

Drouin, J., Y.L. Sun, M. Chamberland, Y. Gauthier, A. De Lean, M. Nemer, and T.J. Schmidt. 1993. Novel glucocorticoid receptor complex with DNA element of the hormone-repressed POMC gene. EMBO I. 12: 145-156.

Evans., R.M. and J.L. Arriza. 1989. A molecular framework for the actions of glucocorticoid hormones in the nervous system. Neuron 2: 1105-1112.

Funder, J.W., P.T. Pearce, R. Smith, and A.I. Smith. 1988. Mineralocorticoid action: Target tissue specificity is enzyme, not receptor mediated. Science 242: 583-585.

Gomez-Sanchez, C., B.A. Murray, D.C. Kem, and N.M. Kaplan. 1975. A direct radioimmunoassay for corticosterone in rat serum. Endocrinology 86: 796-798.

Gorski, K., M. Carneiro, and U. Schibler. 1986. Tissue-specific in vitro transcription from the mouse albumin promoter. Cell 44: 565-576.

Guillemot, F. and A.L. Joyner. 1993. Dynamic expression of the murine achaete-scute homologue Mash-1 in the developing nervous system. 1993. Mech. Dev. 42: 171-185.

Guillemot, F., L.-C. Lo, J.E. Johnson, A. Auerbach, D.J. Anderson, and A.L. Joyner. 1993. Mammalian achaete-scute homolog 1 is required for early development of olfactory and autonomic neurons. Cell 75: 463-476.

Haagsman, H.P. and L.M.G. van Golde. 1991. Synthesis and assembly of lung surfactant. Annu. Rev. Physiol. 53: 441464.

Imai, E., J.N. Miner, J.A. Mitchell, K.R. Yamamoto, and D.K. Granner. 1993. Glucocorticoid receptor-cAMP response element-binding protein interaction and the response of the phosphoenolpyruvate carboxykinase gene to glucocorticoids. J. Biol. Chem. 268: 5353-5356.

Jantzen, H.-M., U. Strähle, B. Gloss, F. Stewart, W. Schmid, M. Boshart, R. Miksicek, and G. Schütz. 1987. Cooperativity of glucocorticoid response elements located far upstream of the tyrosine aminotransferase gene. Cell 49: 29-38.

Jiang, W., R. Uht, and M.C. Bohn. 1989. Regulation of phenylethanolamine $\mathrm{N}$-methyltransferase (PNMT) mRNA in the rat adrenal medulla by corticosterone. Int. I. Dev. Neurosci. 7: 513-520.

Johnson, R.S., B.M. Spiegelman and V. Papaioannou. 1992. Pleiotropic effects of a null mutation in the c-fos proto-oncogene. Cell 71: 577-586.
Klein, R., R.J. Smeyne, W. Wurst, L.K. Long, B.A. Auerbach, A.L. Joyner, and M. Barbacid. 1993. Targeted disruption of the trkB neurotrophin receptor gene results in nervous system lesions and neonatal death. Cell 75: 113-122.

LeMeur, M., N. Glanville, J.L. Mandel, P. Gerlinger, R. Palmiter, and P. Chambon. 1981. The ovalbumin gene family: Hormonal control of $\mathrm{X}$ and $\mathrm{Y}$ gene transcription and mRNA accumulation. Cell 23: 561-571.

Lucas, P.C. and D.K. Granner. 1992. Hormone response domains in gene transcription. Annu. Rev. Biochem. 61: 11311173.

Lufkin, T., D. Lohnes, M. Mark, A. Dierich, P. Gorry, M.-P. Gaub, M. LeMeur, and P. Chambon. 1993. High postnatal lethality and testis degeneration in retinoic acid receptor $\alpha$ mutant mice. Proc. Natl. Acad. Sci. 90: 7225-7229.

Mallampalli, R.K., M.E. Walter, M.W. Peterson, and G.W. Hunninghake. 1994. Betamethasone activation of CTP:cholinephosphate cytidylyltransferase in vivo is lipid dependent. Am. J. Respir. Cell Mol. Biol. 10: 48-57.

Mendelson, C.R. and V. Boggaram. 1991. Hormonal control of the surfactant system in fetal lung. Annu. Rev. Physiol. 53: 415-440.

Michelsohn, A.M. and D.J. Anderson. 1992. Changes in competence determine the timing of two sequential glucocorticoid effects on sympathoadrenal progenitors. Neuron 8: 589-604.

Montoliu, L., J.A. Blendy, T.J. Cole, and G. Schütz. 1995. Analysis of perinatal gene expression: Hormone response elements mediate activation of a LacZ reporter gene in liver of transgenic mice. Proc. Natl. Acad. Sci. 92: 4244-4248.

Muglia, L., L. Jacobson, P. Dikkes, and J.A. Majzoub. 1995. Corticotropin-releasing hormone deficiency reveals major fetal but not adult glucocorticoid need. Nature 373: 427-432.

Müller, T.H. and K. Unsicker. 1981. High-performance liquid chromatography with electrochemical detection as a highly efficient tool for studying catecholaminergic systems. I. Quantification of noradrenaline, adrenaline and dopamine in cultured adrenal medullary cells. I. Neurosci. Methods 4: $39-52$.

Munck, A. and P.M. Guyre. 1991. Glucocorticoids and immune function. In Psyschoneuroimmunology, 2nd ed., pp. 447-474. Academic Press, San Diego, California.

Murphy, D., P.M. Brickell, D.S. Latchman, K. Willison, and P.W.J. Rigby. 1983. Transcripts regulated during normal embryonic development and oncogenic transformation share a repetitive element. Cell 35: 865-871.

Nicholson, W.E., D.R. Davis, B.J. Sherrell, and D.N. Orth. 1984 Rapid radioimmunoassay for corticotropin in unextracted human plasma. Clin. Chem. 30: 259-265.

Ogawa, H., D.A. Miller, T. Dunn, Y. Su, J.M. Burcham, C. Peraino, M. Fujioka, K. Babcock, and H.C. Pitot. 1988. Isolation and nucleotide sequence of the cDNA for rat liver serine dehydratase mRNA and structures of the $5^{\prime}$ and $3^{\prime}$ flanking regions of the serine dehydratase gene. Proc. Natl Acad. Sci. 85: 5809-5813.

Orth, D.N., W.J. Kovacs, and C.R. DeBold. 1992. The adrenal cortex. In Williams textbook of endocrinology, 8th ed., (ed. J.D. Wilson and D.W. Foster), Vol. 9, pp. 489-620. Saunders, London, UK.

Patterson, P.H. 1990. Control of cell fate in a vertebrate neurogenic lineage. Cell 62: 1035-1038.

Pilkis, S.J. and D.K. Granner. 1992. Molecular physiology of the regulation of hepatic gluconeogenesis and glycolysis. Annu. Rev. Physiol. 54: 885-909.

Ruppert, S., M. Boshart, F.X. Bosch, W. Schmid, R.E.K. Fournier, and G. Schütz. 1990. Two genetically defined trans-acting 
loci coordinately regulate overlapping sets of liver-specific genes. Cell 61: 895-904.

Rupprecht, R., J.L. Arriza, D. Sprengler, J.M.H.M. Reul, R.M. Evans, F. Holsboer, and K. Damm. 1993. Transactivation and synergistic properties of the mineralocorticoid receptor: Relationship to the glucocorticoid receptor. Mol. Endocrinol. 7: 597-603.

Sambrook, J., E.F. Fritsch, and T. Maniatis. 1989. Molecular cloning: A laboratory manual. 2nd ed., Cold Spring Harbor Laboratory, Cold Spring Harbor, New York.

Slotkin, T.A. and F.J. Seidler. 1988. Adrenomedullary catecholamine release in fetus and newborn: Secretory mechanisms and their role in stress and survival. J. Dev. Physiol. 10: 116.

Strähle U., A. Schmidt, G. Kelsey, A.F. Stewart, T.J. Cole, W. Schmid, and G. Schütz. 1992. At least three promoters direct expression of the mouse glucocorticoid receptor gene. Proc. Natl. Acad. Sci. 89: 6731-6735.

$\mathrm{Su}$, Y. and H.C. Pitot. 1992. Identification of regions in the rat serine dehydratase gene responsible for regulation by cyclic AMP alone and in the presence of glucocorticoids. Mol. Cell. Endocrinol. 90: 141-146.

te Riele H., E. Robanus Maandag, and A. Berns. 1992. Highly efficient gene targeting in embryonic stem cells through homologous recombination with isogenic DNA constructs. Proc. Natl. Acad. Sci. 89: 5128-5132.

Wilkinson, D.G. 1992. In situ hybridization. A practical approach. Oxford University Press, Oxford, UK.

Yamamoto K.R. 1985. Steroid receptor regulated transcription of specific genes and gene networks. Annu. Rev. Genet. 19: 209-252. 


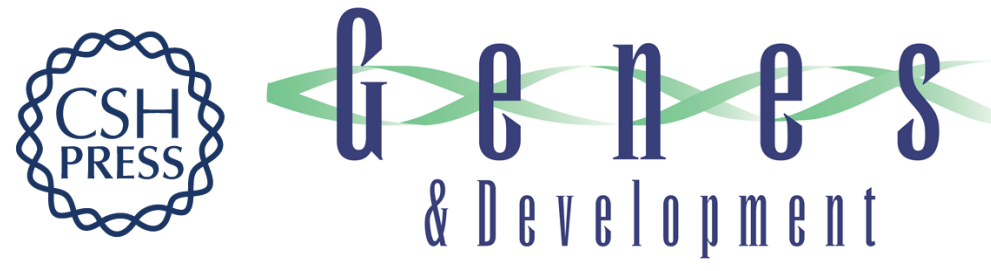

\section{Targeted disruption of the glucocorticoid receptor gene blocks adrenergic chromaffin cell development and severely retards lung maturation.}

T J Cole, J A Blendy, A P Monaghan, et al.

Genes Dev. 1995, 9:

Access the most recent version at doi:10.1101/gad.9.13.1608

References This article cites 48 articles, 9 of which can be accessed free at:

http://genesdev.cshlp.org/content/9/13/1608.full.html\#ref-list-1

License

Email Alerting

Service

Receive free email alerts when new articles cite this article - sign up in the box at the top right corner of the article or click here.

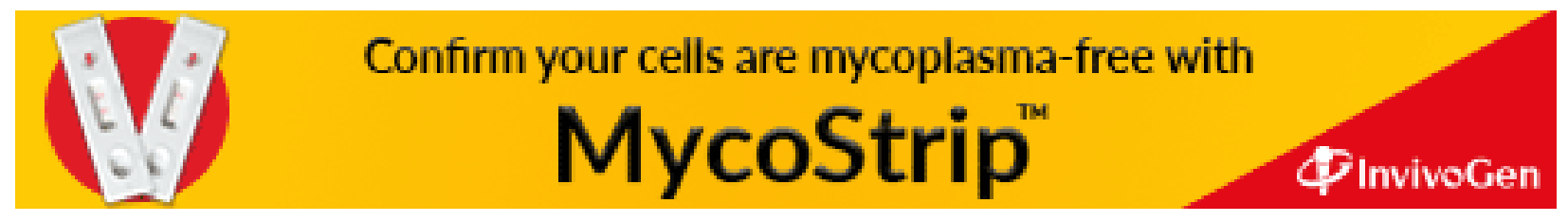

